\title{
Deed Legal Ad / ART PT Perkebunan Nusantara IX After The Consolidated PTP XV-XVI (Persero) With PTP XVIII (Persero)
}

\author{
Meilyna Dwijanti ${ }^{1}$ and Amin Purnawan ${ }^{2}$
}

Abstract. The purpose of this study was to determine the legality of the deed of $A D$ / ART PT Perkebunan Nusantara IX after the consolidation of PTP XV-XVI (Persero) with PTP XVIII (Persero). This research method using normative legal research. The data used is secondary data that is material that provides an explanation of primary legal materials; in the form of deed of AD / ART PT Perkebunan Nusantara IX. Data were analyzed by descriptive qualitative method. The results showed Deeds AD / ART PT Perkebunan Nusantara IX Post-Consolidation PTP XV-XVI (Persero) With PTP XVIII (Persero), in accordance with the process and the provisions of the legislation in force. In the Deed clearly contain 1) the name and domicile of the Company; 2 ) the purpose and objectives and business activities of the Company; 3) The period of the founding of the Company; 4) the amount of the authorized, issued and paid-up capital; 5) the number of shares, class of shares if there is a following for each classification number of shares, the rights attached to each share, and the nominal value of each share; 6 ) the name of position and the number of members of the Board of Directors and Board of Commissioners; 7) determination of the place and manner of implementation of the GMS; 8) procedures for the appointment, replacement, dismissal of members of the Board of Directors and Board of Commissioners; 9) procedures for the use of profits and dividend distribution. replacement, dismissal of members of the Board of Directors and Board of Commissioners; 9) procedures for the use of profits and dividend distribution. replacement, dismissal of members of the Board of Directors and Board of Commissioners; 9) procedures for the use of profits and dividend distribution.

Keywords: Legality; Deeds; AD / ART; Limited Liability Company; BUMN.

\section{Introduction}

The Republic of Indonesia established the state-owned enterprises (BUMN) whose purpose is the pursuit of profit and the natural order to contribute to the development of the national economy in general and state revenues in particular. Forms used by the country's state-owned enterprises, limited companies (Persero). Article 1 paragraph 1 of Act No. 19 of 2003 (hereinafter referred to as Act No. 19 of 2003) states that the limited liability BUMN (PT), because Persero PT, then the Limited is a private legal entity, not a legal entity of public ${ }^{3}$, Limited is a limited liability company, the limited company should be subject to legal consequences attached to the principles of limited liability laws and legal

\footnotetext{
${ }^{1}$ Student of Master of Law, Universitas Islam Sultan Agung Semarang and PNS in the Court of Semarang email: meilynadwijanti@gmail.com

${ }^{2}$ Lecturer of Faculty of Law UNISSULA Semarang

${ }^{3}$ Ridwan Khairandy Karakter Hukum Perusahaan Perseroan dan Status Hukum Kekayaan yang Dimilikinya Jurnal Hukum lus Quia lustum No. 1 Vol. 20 (2013).
} 
provisions regarding the limited liability company as regulated in Law Number 40 Of 2007 regarding Limited Liability Company (hereinafter referred to as Act No. 40 of 2007 ).

Broadly speaking, an entity comprised of two (2) types, namely enterprises which are not legal entities and business entities with legal status. Business entity that is not a legal entity is the Guild civil liability company (CV), Firm Partnership, Trading Company (PD). Whereas, the business entity is a legal entity is a Limited Liability Company (PT) (PT), Cooperative and the Foundation. The most fundamental difference between the two which is not a legal entity and legal entity is situated on the responsibility of the owner of a Limited Liability Company (PT).

The characteristics of a Limited Liability Company (PT) as a legal entity is as follows ${ }^{4}$ :

- Has a wealth of riches Separate and Apart from the people who run the legal entity.

- Rights and duties separate from the rights and obligations of those who run such legal entity.

- Have a Vision and Mission Specific

Its existence is not tied to a particular person, because the rights and obligations remain even though the people who run it changed. Deed is an inscription which was deliberately made to order to be used as a proof of a legal event and signed by the parties in relation to an event such laws. Under the provisions of Article 1867 of the Civil Code is divided into a deed, deed under the hand and official deed / Authentic. Asshiddiqie ${ }^{5}$, Confirmed that the organization is a legal entity, as well as state-owned enterprises, require Statutes which usually comes with the Bylaws. Articles of Association of legal entities can be regarded as the constitutional function of BUMN organization.

Processes in deed a Limited Liability Company Law Board to be authentic, which is entrusted to the Notary. Notary Public Officials deed is working professionally. Deed of Establishment of Limited Liability Company that was created and then forwarded to the Ratification by the Ministry of Law and Human Rights through Sisminbakum to be examined over the internet. After examination of the Internet followed by a physical examination of the data submitted by the authentic deed Notary ${ }^{6}$,

BUMN change as happened in PTP XV-XVI (Persero) with PTP XVIII (Persero) were consolidated into PT Perkebunan Nusantara IX, requiring a change in the deed of the Articles of Association at the same time new Bylaws. Consolidation is another form of merger, the merger with the way the company merged with another company to form a new company. PT Perkebunan Nusantara IX (Persero) was established on March 11, 1996 under Government Regulation No. 14 of 1996 dated February 14, 1996, is an amalgamation of PT Perkebunan XV-XVI and PT Perkebunan XVIII', Establishment PT Perkebunan Nusantara IX (Persero) is contained in the Deed of Harun Kamil, SH No. 42 dated March 11, 1996, authorized by the Minister of Justice No. C2-8337.HT.01.01.TH.96

\footnotetext{
${ }^{4}$ Mochtar Kusumaatmaja dan B. Arief Sidartha 2000 Pengantar Ilmu Hukum dan Ruang Lingkup Hukum Buku 1 Alumni Bandung p82-83.

5 Jimly Asshiddiqie 2010 Konstitusi Ekonomi PT Kompas Media Nusantara Jakarta p 5.

6 John Edong Tinjauan Yuridis Perubahan Undang-undang Perseroan Terbatas Jurnal Hukum Legal Opinion Edisi 5 Volume 2 (2014) p 85

${ }^{7}$ Government Regulation No. 14 of 1996. About. Smelting Company (Persero) PT Perkebunan XV-XVI and Limited Liability Company (Persero) PT Perkebunan XVIII into a Limited Liability Company (Persero) PT Perkebunan Nusantara IX
} 
dated August 8, 1996, amended by the notary Sri Rahayu Hadi Prasetyo, SH 1 August 9, 2002 and ratified by the Decree of the Minister of Justice and Human Rights No. C-19302 HT.01.04.TH.2002 7 October $2002^{8}$.

PTPN IX is located in Central Java, with the number of work units 15 Gardens, 1 and 8 Agro Business Unit Sugar Factory. PTPN IX manage commodities such as rubber, Tea, Coffee and Sugar / Sugar and melaksaakan form Agro tourism diversification and downstream industries. PT. Perkebunan Nusantara IX (Persero) which is engaged in four major commodities such as rubber, sugar, tea, and coffee is the result of amalgamation of PT. Perkebunan XV-XVI (Persero) and PT. Perkebunan XVIII (Persero) in $1996 .{ }^{9}$ This means that existing efficiency efforts have been taken by the Ministry of BUMN to achieve BUMN appropriate in accordance with what is mandated by Act No. 19 of 2003 on BUMN.

PT Perkebunan Nusantara IX has two Division. First, the Annual Plant Division (DTT) who grow and produce products from rubber, coffee, and tea. Second, the Division of Plant Annuals (DTS) (sugar factory) which produce products from sugar cane. Products PT Perkebunan Nusantara IX marketed in the domestic market and the overseas markets. PT Perkebunan Nusantara IX also manufactures and markets downstream products such as packaged tea, tea bags, as well as sugar and coffee powder in the box.

In operasionalisasinya Division of Plant Annuals (DTS) does not have sugar cane land and have no land to businesses because no Hak Guna Usaha (HGU). The problem is that when it wants to grow sugar cane DTS, if the first easy to lease land from the community, but in fact now DTS difficult to lease the land because of high rental rates, the result is the production of sugar is difficult and losers. The existence of the DTS is the responsibility of DTT so that the purpose of government commit smelting company was not in line with expectations smelting contained in the AD / ART PTPN IX Indonesian Government Regulation No. 14 of 1996 on the Consolidation of the Company (Persero) PT Perkebunan XV-XVI and liability company (Persero) PT Perkebunan XVIII into liability company (Persero) PT. Perkebunan Nusantara IX. ${ }^{10}$

Problems that occur at the top, with the degradation of value widened a division of PT. Perkebunan Nusantara IX. According to one employee of PT. Perkebunan Nusantara IX, DTS credibility decreases, resulting in improved performance by the banking institutions difficult to realize. Consolidation conditions are expected to be more effective and efficient, turn out to be less convenient. There is an atmosphere tensions between DTS with DT, which resulted in management indecision assumptions in following the consolidation decision. It is then interesting to deepening the study of law, with the title,? Legal Deed of AD / ART PT Perkebunan Nusantara IX Post-Consolidation PTP XV-XVI (Persero) With PTP XVIII (Persero)".

As the above description, the formulation of the problem in the study of this law is how the Legal Deed AD / ART PT Perkebunan Nusantara IX Post-Consolidation PTP XV-XVI (Persero) With PTP XVIII (Persero)?

\footnotetext{
${ }^{8}$ Decision Minister Justice and Human Rights No. C-19302 HT.01.04.TH.2002 7 October 2002

9 PTPN IX ?Tentang Perusahaan http://www.bumn.go.id/ptpn9/tentang-kami/tentang-perusahaan/ BUMN accessed on March 312018.

${ }^{10}$ Results of preliminary observations and interviews with Mr. SM one of the employees of PT. Perkebunan Nusantara IX on Friday at the date of March 302018.
} 


\section{Research Methods}

Law research used in writing this law is a normative legal research or legal research doctrine or library research (doctrinal research) where the author only answer legal issues in layers dogmatif law made by examining the library materials or secondary data consists of primary legal materials and secondary law. The approach used in the study of law is the approach of legislation (state approach), the approach of the case (case approach), the historical approach (historical approach), a comparative approach and the conceptual approach. $^{11}$

The sources used in this study a writing legal materials of primary and secondary legal materials. Primary legal materials consist of legislation, official records or minutes of the legislation and the judge's decision. While the secondary law in the form of all publications on the law which is not an official documents. Data collection techniques in this research is the study of literature.

After the data is collected, then processed and analyzed using qualitative descriptive analysis and subsequent conclusions drawn by using the deductive method, which is an interesting fact or conclusions of a general nature, to be used as a general fact or conclusions of a special nature. ${ }^{12}$

\section{Results and Discussion}

Based on the survey results revealed that the deed of AD / ART PT Perkebunan Nusantara IX Post-Consolidated, has been through the process in accordance with the laws and regulations that apply and meet the required legal aspects. The deed of establishment including articles of association and other information relating to the establishment of the Company. In principle, in addition subject to the Act No. 40 About Company Limited (Company Law) a company should also be subject to the articles of association of the Company that have been defined. In other words, the articles of association is the rule in a limited liability company. ${ }^{13}$

Statutes minimum load; 1 ) name and domicile of the Company; 2) the purpose and objectives and business activities of the Company; 3 ) The period of the founding of the Company; 4) the amount of the authorized, issued and paid-up capital; 5) the number of shares, class of shares if there is a following for each classification number of shares, the rights attached to each share, and the nominal value of each share; 6) the name of position and the number of members of the Board of Directors and Board of Commissioners; 7) determination of the place and manner of implementation of the GMS; 8) procedures for the appointment, replacement, dismissal of members of the Board of Directors and Board of Commissioners; 9) procedures for the use of profits and dividend distribution.

Research findings showed, deed of AD / ART PT Perkebunan Nusantara IX PostConsolidation. In deed AD / ART PT Perkebunan Nusantara IX Post-Consolidation mentioned in the following visual.

\footnotetext{
${ }^{11}$ Peter Mahmud Marzuki 2010 Penelitian Hukum Kencana Prenada Media Group Jakarta p. 93-95.

${ }^{12}$ Sutrisno Hadi 2007 Metodologi Penelitian Research PT. Moyo Segoro Agung Jakarta p. 56.

${ }^{13}$ Article 4 of the Company Law: The Company applies this law the articles of association of the Company and the provisions of other legislation.
} 


$$
\begin{aligned}
& \text { Here the original one (In Indonesian Language); } \\
& \text { KTP Nomor : : } 450232467.0404500424 .
\end{aligned}
$$

Figure 1. Pieces AD / ART PTPN IX after consolidation

Statutes can also contain other provisions not contrary to the law of origin. If there is a conflict between the statutes and Company Law, shall prevail Company Law. ${ }^{14}$ The articles of association shall not contain: 1 ) the provision of fixed interest receipts for shares; and the rules on granting personal benefits to the founders or other parties.

Related to the Company's name there are several things that must be addressed as follows:

- Article 16 of the Company Law stipulates that liability company may not use a name that: a) have been used legally by another company or the same in principle with the name of another company; b). contrary to public order and / or morality; c). the same or similar to the name of the state institutions, government agencies, international agencies, except by permission of the concerned; d) does not comply with the intent and purpose, as well as business activities, or show purposes and objectives of the Company without proper name; e). consist of a number or series of numbers, letters or a series of letters that do not form words; or f). have meaning as the Company's legal entity, or civil partnership.

- The Company's name should be preceded by the phrase Company Limitedor abbreviated PT.

- In the case of listed companies in addition to the provisions referred to in No. 2 above, at the end of the Company's name plus the word stands for Tbk. If there is no written abbreviation Tbk, means the Company's status as closed.

- Further provisions on the procedure use of the name of the Company is regulated by the Government.

The Company has the locus (also the headquarters) of the Company in the city or county in Indonesian territory specified in the statutes. This provision does not rule out the possibility of the Company has a domicile in the village or in the district along the base budget includes the name of your city or county of the village and the township. The Company shall have the intent and purpose (the main business companies) and business activities are included in the articles of association of the Company in accordance with the provisions of the legislation (Article 18 of the Company Law).

\section{Closing}

\subsection{Conclusion}

Based on the study above, it can be concluded that the Deed of AD / ART PT Perkebunan Nusantara IX Post-Consolidation PTP XV-XVI (Persero) With PTP XVIII (Persero), in accordance with the process and the provisions of the legislation in force. Deed Harun Kamil, SH No. 42 dated March 11, 1996, authorized by the Minister of Justice No. C28337.HT.01.01.TH.96 dated August 8, 1996, amended by the Deed Sri Rahayu Hadi

\footnotetext{
${ }^{14}$ Explanation Article 4 of the Company Law
} 
Prasetyo, SH 1 date August 9, 2002 and ratified by the Decree of the Minister of Justice and Human Rights No. C-19302 HT.01.04.TH.2002 7 October 2002, meets the elements 1) the name and domicile of the Company; 2) the purpose and objectives and business activities of the Company; 3 ) The period of the founding of the Company; 4) the amount of the authorized, issued and paid-up capital; 5) the number of shares, class of shares if there is the following number of shares for each classification, the rights attached to each share, and the nominal value of each share; 6 ) the name of position and the number of members of the Board of Directors and Board of Commissioners; 7) determination of the place and manner of implementation of the GMS; 8) procedures for the appointment, replacement, dismissal of members of the Board of Directors and Board of Commissioners; 9) procedures for the use of profits and dividend distribution.

\subsection{Suggestion}

These findings should be used as an input to entrepreneurs who want to consolidate with another company. Fulfillment of legality certificate is needed so that the consolidation of the legal function contained in the AD / ART organization can be used as a reference in the management of the company. When a deviation occurs in the management company and does not match the AD / ART has been determined, then the deviation can be completed according to the corridors of applicable law.

\section{Bibliography}

[1] Jimly Asshiddiqie 2010 Konstitusi Ekonomi PT Kompas Media Nusantara Jakarta.

[2] John Edong Tinjauan Yuridis Perubahan Undang-undang Perseroan Terbatas Jurnal Hukum Legal Opinion Edisi 5 Volume 2 (2014).

[3] Keputusan Menteri Kehakiman dan Hak Asasi Manusia Nomor: C-19302 HT.01.04.TH.2002 tanggal 7 Oktober 2002

[4] Mochtar Kusumaatmaja dan B. Arief Sidartha 2000 Pengantar Ilmu Hukum dan Ruang Lingkup Hukum Buku 1 Alumni Bandung.

[5] Peraturan Pemerintah Nomor 14 Tahun 1996. Tentang. Peleburan Perusahaan Perseroan (Persero) PT Perkebunan XV-XVI dan Perusahaan Perseroan (Persero) PT Perkebunan XVIII menjadi Perusahaan Perseroan (Persero) PT Perkebunan Nusantara IX

[6] Peter Mahmud Marzuki 2010 Penelitian Hukum Kencana Prenada Media Group Jakarta.

[7] PTPN IX ??Tentang Perusahaan" http://www.bumn.go.id/ptpn9/tentangkami/tentang-perusahaan/BUMN diakses pada 31 Maret 2018.

[8] Ridwan Khairandy Karakter Hukum Perusahaan Perseroan dan Status Hukum Kekayaan yang Dimilikinya Jurnal Hukum lus Quia lustum No. 1 Vol. 20 (2013).

[9] Sutrisno Hadi 2007 Metodologi Penelitian Research PT. Moyo Segoro Agung Jakarta.

[10] Act No. 40 on Company Limited (Company Law)

[11] Act No. 19 of 2003 on State-Owned Enterprises

[12] Decision Minister Justice and Human Rights No. C-19302 HT.01.04.TH.2002 7 October 2002 